JPPIPA, Vol. 3 No. 22018
Jurnal Penelitian Pendidikan IPA
http://journal.unesa.ac.id/index.php/jppipa

\title{
PENINGKATAN KEMAMPUAN MENDESKRIPSIKAN PROSES PEMBENTUKAN BAYANGAN MELALUI MEDIA ANIMASI PADA SISWA KELAS VIII-G SMPN 1 PUNCU
}

Oleh:

Widyanti Nugraheni ${ }^{1}$,

${ }^{1}$ UPTD SMP Negeri 1 Puncu, Negara Indonesia

\begin{abstract}
Abstrak
Penelitian ini dilakukan untuk meningkatkan kemampuan mendeskripsikan proses pembentukan bayangan pada siswa kelas VIII-G SMPN 1 Puncu, dengan menggunakan media animasi powerpoint. Metode penelitian yang digunakan adalah metode penelitian tindakan kelas dengan 2 siklus. Penelitian ini menggunakan indikator keberhasilan kemampuan mendeskripsikan proses pembentukan bayangan sebesar 75. Hasil penelitian siklus I: rata-rata kemampuan identifikasi siswa : 64,5, pada siklus II: 77,8. Berdasarkan hasil penelitian tersebut dapat disimpulkan bahwa penggunaan media animasi powerpoint dapat meningkatkan kemampuan siswa kelas VIII-G SMPN 1 Puncu dalam mendeskripsikan proses pembentukan bayangan pada peristiwa pemantulan dan pembiasan.
\end{abstract}

Kata Kunci: Proses pembentukan bayangan, media animasi

\begin{abstract}
This research was conducted to improve the ability to describe the process of shadows forming in class VIII-G of SMP 1 Puncu facilitated by animation media. The method is classroom action research method with two cycles. This media is effective if student achieve 75 for post test score. The results of the first cycle of research: the average identification ability of students: 64.5, in the second cycle: 77.8. Based on the results of these studies it can be concluded that the use of animation media can improve the ability of class VIII-G students of SMP 1 Puncu in describing the process of forming shadows in the event of reflection and refraction.
\end{abstract}

Keywords: Process of shadow formation, animation media

(C) 2018 Universitas Negeri Surabaya

${ }^{2}$ Alamat Korespondensi:

UPTD SMP NEGERI 1 PUNCU

p-ISSN: $2527-7537$

e-ISSN: 2549-2209

E-mail: nunukwn@gmail.com

\section{PENDAHULUAN}

Menurut Permendiknas No 22 Tahun 2016, Ilmu Pengetahuan Alam (IPA) berkaitan dengan cara mencari tahu tentang alam secara sistematis, sehingga IPA bukan hanya penguasaan kumpulan pengetahuan yang berupa fakta fakta, konsepkonsep, atau prinsip-prinsip saja tetapi juga merupakan suatu proses penemuan.

Materi IPA mencakup fakta, konsep/prinsip serta proses untuk menemukan fakta atau konsep tersebut. Sederhananya, IPA mengandung unsur teori (fakta, konsep, prinsip) dan praktek (proses). Praktek dalam pembelajaran IPA merupakan suatu keniscayaan agar siswa lebih mudah dalam memahami suatu konsep. Pun demikian dalam materi Cahaya, khususnya sub konsep Pemantulan dan Pembiasan.
Karakteristik siswa SMP Negeri I Puncu khususnya kelas VIII-G tahun pelajaran 20172018, memiliki kecenderungan senang diajak melakukan aktivitas yang melibatkan motorik. Pelaksanaan praktikum dalam materi cahaya, seringkali mendapatkan kendala. Kendala yang ada dapat berupa kendala sarana/prasarana maupun kendala pemahaman siswa. Kendala sarana/ prasarana diantaranya adalah tidak tersedianya ruang gelap, kondisi peralatan yang tidak presisi, serta jumlah KIT cahaya yang tersedia di laboratorium hanya 2 boks. Jumlah tersebut tentu saja tidak cukup untuk memenuhi kebutuhan praktikum siswa dalam satu kelas. Kendala yang ada ini perlu dicarikan solusi pemecahannya. 
De Potter dan Hernacki (2006) menyebutkan bahwa ada tiga modalitas (kecenderungan) belajar yang berbeda pada tiap siswa yaitu visual, auditorial dan kinestetik. Proses pembelajaran yang baik harus menggunakan model yang bervariasi, untuk memfasilitasi berbagai gaya belajar siswa tersebut. Selain itu, keterlibatan siswa secara aktif dalam proses pembelajaran sangat mempengaruhi keberhasilan siswa. Demikian juga, penggunaan media sangat membantu terciptanya proses pembelajaran yang dinamis (melibatkan siswa).

Model pembelajaran langsung atau direct instruction menuntut siswa untuk mempelajari suatu keterampilan dasar dan memperoleh informasi yang dapat diajarkan selangkah demi selangkah. Model pembelajaran ini dirancang khusus untuk mengembangkan pembelajaran siswa baik yang berkaitan dengan pengetahuan prosedural maupun pengetahuan deklaratif yang tersusun dengan baik dan dapat diajarkan selangkah demi selangkah. Kompetensi dasar mendeskripsikan proses sangat tepat jika disajikan dengan model pembelajaran ini. Model pembelajaran ini juga mensyaratkan keterlibatan siswa secara penuh selama prosesnya.

Sintak model DI pada dasarnya mencakup tiga kegiatan utama, yaitu: 1) presentasi, 2) latihan,dan 3) penilaian dan evaluasi. Presentasi mencakup kegiatan pendahuluan dan penjelasan singkat dari guru. Kegiatan latihan merupakan kegiatan pemberian latihan kepada siswa, baik secara terbimbing maupun secara mandiri. Selama pemberian penjelasan dan latihan terbimbing, guru melaksanakan pengecekan pemahaman siswa dan menanggapinya. Selama kegiatan latihan mandiri, guru melaksanakan review secara periodik.

Penelitian ini menggunakan media animasi dengan bantuan software powerpoint. PowerPoint merupakan program untuk membantu mempresentasikan dan menampilkan presentasi dalam bentuk tulisan, gambar, grafik, objek, clipart, movie, suara, atau video yang dapat dimainkan pada saat presentasi (Purnomo, 2008).

Animasi termasuk dalam kategori media visual, dengan daya liput yang terbatas pada ruang dan waktu, serta termasuk dalam media yang harus diproyeksikan. Sedangkan berdasarkan definisi dalam buku PKB, maka media yang penulis pakai dalam penelitian ini termasuk ke dalam sub unsur alat peraga. Animasi yang penulis buat, digunakan untuk memperjelas cara kerja/prosedur dalam melukis pembentukan bayangan, baik dalam peristiwa pemantulan maupun peristiwa pembiasan.

Berdasarkan kurikulum KTSP 2006, materi IPA untuk kelas VIII terdiri dari 6 SK. Diantara SK tersebut adalah "6. Memahami konsep dan penerapan getaran, gelombang dan optika dalam produk teknologi sehari-hari”. Kompetensi dasar yang membahas tentang Cahaya adalah 6.3. Menyelidiki sifat-sifat cahaya dan hubungannya dengan berbagai bentuk cermin dan lensa.

Indikator dari KD 6.3 yang tercantum di dalam silabus, diantaranya berbunyi: 1) siswa mampu mendiskripsikan proses pembentukan dan sifat-sifat bayangan pada cermin datar, cermin cekung dan cembung, serta 2) siswa mampu mendiskripsikan proses pembentukan dan sifatsifat bayangan pada lensa cembung dan lensa cekung.

Kemampuan mendeskripsikan proses, dapat dicapai jika siswa melakukan sendiri proses tersebut. Dalam melakukan proses diperlukan pemahaman, ketrampilan dan ketelitian. Pemahaman yang dimaksud adalah pemahaman terhadap kalimat pada sifat-sifat sinar istimewa yang berlaku pada cermin dan lensa, serta notasinotasi yang diperlukan dalam media gambar. Ketrampilan diperlukan dalam menggunakan alat dan bahan dalam melukis jalannya sinar pada media gambar. Sedangkan ketelitian diperlukan dalam ketepatan meletakkan garis pada notasi yang sesuai dan tepat, karena ketika cara melukisnya tidak teliti, maka ketiga garis sinar istimewa tidak akan membuat satu titik potong sebagai hasil pemantulan atau pembiasan.

Proses pembentukan bayangan pada peristiwa pemantulan dan pembiasan, melibatkan tiga sinar istimewa. Masing-masing alat optik, memiliki sinar istimewa yang berbeda dengan alat optik yang lain. Kemampuan siswa menerjemahkan sinar-sinar istimewa tersebut, sangat mempengaruhi proses melukis pembentukan bayangan. Melalui media animasi, siswa sangat terbantu dengan melihat secara nyata proses datangnya sinar, maupun proses pemantulan dan pembiasannya. Demikian juga ketika sinar bias dan sinar pantul yang tidak bertemu dalam satu titik, siswa dapat mengetahui asal muasal dari 
pembentukan garis perpanjangan sinar pantul/sinar bias tersebut.

Titik potong sinar pantul/sinar bias, dengan mudah diketahui sebagai letak terbentuknya bayangan. Bentuk bayangan yang terjadi dapat didefinisikan sifatnya secara kasat mata dan jelas.

Setelah guru mendemonstrasikan pembentukan bayangan, kemudian guru meminta siswa melukiskan proses pembentukan bayangan secara terbimbing, dan pada akhirnya siswa dapat melakukan proses pembentukan bayangan secara mandiri, untuk posisi benda yang lain.

Penelitian ini bertujuan Meningkatkan kemampuan mendeskripsikan proses pembentukan bayangan pada peristiwa pemantulan dan pembiasan. Secara khhusus, penelitian ini dapat pula meningkatkan kemampuan siswa dalam melukis pembentukan bayangan serta mengidentifikasi sifat bayangan yang terbentu.

\section{METODE}

Penelitian ini meggunakan metode penelitian tindakan kelas, dengan model pembelajaran direct instruction dan media pembelajaran berupa animasi powerpoint. Sebelum siklus penelitian dimulai, Peneliti mengawali kegiatan dengan langkah pendahuluan. Langkah pendahuluan diantaranya adalah menyiapkan surat izin penelitian serta membuat animasi powerpoint yang hendak dipakai dalam pembelajaran. Siklus PTK mencakup kegiatan perencanaan, aksi/ tindakan, dan diakhiri dengan kegiatan refleksi. Kegiatan perencanaan meliputi (a) penyiapan kerangka penelitian (b) penyiapan lembar observasi (c) menyiapkan perangkat pembelajaran (Silabus, RPP, LKS, dan instrumen penilaian), dan (d) penyiapan lembar angket respon siswa dan guru terhadap pelaksanaan pembelajaran. Tahap tindakan meliputi pelaksanaan pembelajaran oleh peneliti sekaligus pengamatan/observasi yang dilaksanakan oleh kolaborator. Tahap refleksi dilakukan melalui aktivitas diskusi jalannya pembelajaran dari hasil pengamatan kolaborator, serta quesioner yang sudah diisi oleh siswa setelah pembelajaran selesai. Refleksi juga diisi dengan kegiatan koreksi hasil penilaian siswa pada lembar LKS maupun kuis.

Subjek penelitian ini adalah kemampuan mendeskripsikan proses pembentukan bayangan pada peristiwa pemantulan dan pembiasan. Sasaran penelitian ini adalah Siswa kelas VIII-G SMP Negeri 1 Puncu Kab Kediri Tahun Pelajaran 2017-2018.

Instrumen yang digunakan untuk mengumpulkan data antara lain lembar observasi pelaksanaan tindakan (aktivitas guru dan siswa), angket guru dan siswa, lembar notulensi catatan lapangan, lembar evaluasi hasil belajar siswa. Instrumen panduan analisis data yang telah terkumpul meliputi tabel penskoran tes kemampuan mendeskripsikan proses pembentukan bayangan, lembar nilai siswa (dari siklus I dan siklus II), lembar ketuntasan, serta kriteria keberhasilan pembelajaran.

Keberhasilan pelaksanaan penelitian ini dilihat dari indikator kinerjanya, yaitu sebagai berikut: (1) Kategori ketuntasan klasikal termasuk baik, yaitu lebih dari $80 \%$ siswa memperoleh nilai diatas 75, (2) Kriteria keberhasilan pembelajaran tergolong berhasil dengan baik, sesuai dengan tabel keberhasilan pembelajaran $(68 \% \leq \mathrm{Pa} \leq$ $85 \%)$. Jika dalam penelitian ditemukan hasil penelitian kurang dari indikator yang sudah ditentukan, maka dilanjutkan dalam siklus II.

\section{HASIL DAN PEMBAHASAN}

Hasil penelitian berupa (a) hasil belajar siswa tentang kemampuan mendeskripsikan proses pembentukan bayangan, (b) Ketuntasan klasikal, yang dapat dilihat pada Tabel 1, serta keberhasilan pembelajaran, yang dapat dilihat pada tabel 2 .

Tabel 1. Hasil Belajar dan Ketuntasan Klasikal

A. Kemampuan Mendeskripsikan Proses Pembentukan Bayangan

\begin{tabular}{ccc}
\hline & Siklus I & Siklus II \\
\hline Nilai Rata-rata & 64,5 & 77,8 \\
\hline B. Ketuntasan Klasikal & & 32 \\
\hline Jumlah siswa tuntas & 28 & 82,1 \\
\hline Ketuntasan & 71,8 & Tuntas \\
\hline Kriteria & Belum tuntas & \\
\hline
\end{tabular}


Tabel 1.2 Tabel Keberhasilan Pembelajaran

\begin{tabular}{cccccc}
\hline \multirow{2}{*}{ No } & \multirow{2}{*}{ Obyek } & \multicolumn{2}{c}{ Siklus I } & \multicolumn{2}{c}{ Siklu II } \\
\cline { 3 - 6 } & & Prosentase & Kriteria & Prosentase & Kriteria \\
\hline 1. & Siswa & 53 & Cukup & 84 & Baik \\
\hline 2. & Guru & 61 & Cukup & 91 & Sukses \\
\hline & Jumlah & 58 & Cukup & 88 & Sukses \\
\hline
\end{tabular}

Kemampuan mendeskripsikan proses pembentukan bayangan pada siklus I diukur dengan memberikan soal uraian sejumlah 5 butir soal. Secara umum siswa diminta untuk mendeskripsikan proses pembentukan bayangan pada peristiwa pemantulan pada cermin datar, cermin cekung dan cermin cembung setelah melakukan pembelajaran melukis pembentukan bayangan. Nilai yang diperoleh siswa belum mencapai indikator keberhasilan. Ketuntasan klasikal yang didapat sebesar $71,8 \%$, sementara kriteria keberhasilan yaitu $80 \%$. Artinya ketuntasan klasikal belum mencapai kriteria keberhasilan penelitian.

Data observasi merekam adanya aktivitas siswa yang tidak sesuai dengan petunjuk, karena tidak semua siswa membawa peralatan standar yang sudah ditetapkan oleh guru. Hasil observasi menunjukkan bahwa aktivitas siswa yang tidak sesuai dengan petunjuk sebesar 53\%, dengan kriteria cukup. Sementara aktivitas guru menghasilkan nilai 61, dengan kriteria cukup. Hasil ini menunjukkan perolehan nilai dibawah kriteria keberhasilan penelitian.

Catatan lapangan merekam adanya permasalahan yang terjadi, yaitu ditemukannya guru yang mengajar tidak sesuai dengan RPP, ada beberapa sintak DI yang terlewat atau tidak urut (meloncat). Aktivitas siswa yang tidak terekam di lembar observasi adalah saat siswa menarik kesimpulan hasil diskusi, masing-masing siswa dalam kelompok terdapat perbedaan penafsiran hasil lukisan pembentukan bayangannya.

Ketuntasan klasikal dan keberhasilan pembelajaran yang masih dibawah kriteria keberhasilan penelitian, mengharuskan peneliti untuk melanjutkannya pada siklus II. Permasalahan yang muncul pada siklus I mencoba diberikan solusi untuk dilaksanakan pada siklus II. Solusi berupa perbaikan RPP, LKS, serta media animasi.
Perbaikan-perbaikan yang dilakukan terhadap RPP dan LKS memberikan hasil yang bagus pada siklus II, yang ditunjukkan dengan nilai kemampuan mendeskripsikan mencapai 77,8 dengan ketuntasan klasikal sebesar $82,1 \%$. Nilai ini sudah melampaui indikator. Pengukuran kemampuan mendeskripsikan dilakukan dengan memberikan 5 butir soal uraian yang mencakup pendeskripsian proses pembuatan bayangan pada peristiwa pembiasan oleh lensa cekung dan lensa cembung. Sebagai penguatan, diberikan juga soal identifikasi sifat-sifat bayangan yang dibentuk. Untuk mengatasi perbedaan penafsiran hasil lukisan siswa, guru menayangkan kembali slideshow animasi jalannya sinar istimewa dan meminta siswa deskripsi sinarnya.

Permasalahan yang terjadi pada siklus I, telah diberikan solusi yang dilaksanakan dalam siklus II. Penerapan solusi tersebut memberikan hasil aktivitas siswa sudah mencapai nilai $84 \%$, yang artinya aktivitas siswa baik dan aktivitas guru mencapai nilai 91, yang artinya sukses. Ketuntasan klasikal yang dicapai siswa sebesar $82,1 \%$, yang artinya sudah melampaui indikator keberhasilan penelitian. Setiap siswa yang ditanya tentang deskripsi sinar istimewa yang ditayangkan dalam slide animasi powerpoint, dapat menjawab dengan benar.

Dengan dilampauinya indikator keberhasilan penelitian, maka penelitian tidak lagi dilanjutkan ke siklus berikutnya. Dengan demikian, dapat diartikan bahwa media animasi powerpoint dapat meningkatkan kemampuan siswa kelas VIII-G SMPN 1 Puncu, dalam mendeskripsikan proses pembentukan bayangan pada peristiwa pemantulan dan pembiasan.

\section{PENUTUP}

\section{Simpulan}

Penggunaan media animasi powerpoint dengan model pembelajaran DI, dapat meningkatkan kemampuan siswa kelas VIII-G 
SMPN 1 Puncu dalam mendeskripsikan proses pembentukan bayangan pada peristiwa pemantulan dan pembiasan.

\section{Saran}

Saran yang dapat penulis sampaikan untuk peneliti selanjutnya adalah (1) Penelitian sejenis perlu dikembangkan untuk melatihkan kecakapan guru dalam mengembangkan pembelajaran serta melatih kecakapan hidup siswa pada materi lain yang sesuai. (2) Media animasi powerpoint yang dibuat, lebih menarik dan bagus. (3) LKS yang dipakai harus menggunakan bahasa yang mudah dimengerti oleh siswa, sehingga siswa mudah melakukan aktivitas sesuai yang diharapkan. (4) Pengukuran hasil belajar dengan post-test sebaiknya tidak dilakukan pada hari yang sama dilakukannya pembelajaran, namun harus dilakukan pada pertemuan selanjutnya.

\section{DAFTAR PUSTAKA}

Arikunto, Suharsimi, dkk. 2014. Penelitian Tindakan Kelas. Jakarta: PT. Bumi Aksara.

DePorter, Bobbi dan Hernacki, Mike. 2006. Quantum Learning: Membiasakan Belajar Nyaman \& Menyenangkan. Bandung: PT.Mizah Pustaka.

Huitt, W., Monetti, D., dan Hummel J. 2009. Designing direct instruction. Pre-publication version of chapter published in C. Reigeluth and A. Carr-Chellman. Instructional design theories and models: Volume III. Building a common knowledge base [73-97]. Mahwah, NJ: Lawrence Erlbaum Associates.

Purnomo, C.H. 2008. Panduan Belajar Otodidak Microsoft Power Point 2007. Jakarta: Media Kita. 